\title{
DISTRIBUTING COVID-19 RELIEF FUNDS IN NIGERIA: PERSPECTIVES FROM JOHN RAWLS' DISTRIBUTIVE THEORY OF JUSTICE
}

\author{
Paul T. Haaga \\ Department of Philosophy, Federal University of Lafia, Nigeria \\ Email: paul.haaga.@arts.fulafia.edu.ng \\ Phone: $+2340867666445 \&+2348020540454$
}

\begin{abstract}
This paper argues that every responsible government has an obligation, to the best of its ability, to ensure an adequate provision of economic welfare and healthcare for its citizens. In view of this global pandemic, the Nigerian government, like many other nations, has urgently developed a plan to provide health and economic assistance to the tens of millions of people who are vulnerable. However, the provision of these palliatives by the government designed to assuage the effect of the COVID-19 pandemic on the poor and vulnerable Nigerians is not fairly undertaken. Adopting an expository and analytic approach, this paper examines the role of the government in distributing the COVID- 19 relief funds; in doing this, the questions in this paper are in two fronts: firstly, what constitutes vulnerability and who is vulnerable? Secondly, what is the criterion adopted by the government for determining who benefits from these palliatives? Finally, the paper proposes a model for assessing the role of government in the distribution of palliatives from the prism of John Rawls's principle of distributive justice. This is imperative because the fair distribution of relief funds and benefits from the government will further ease the burdens, and it will fundamentally affect the people's wellbeing.

Keywords: Covid-19; Distributive Justice; Vulnerable, Palliatives, Pandemic, Rawls
\end{abstract}

\section{INTRODUCTION}

The wide spread of Coronavirus 2019, otherwise referred to as Covid-19, all over the world is devastating. This has prompted most world leaders to employ adequate measures in order to prevent it from further spreading. The pandemic has become the matter of concern and a topic of deliberation across the globe because of its apparent impact on all countries of the world. This virus is said to have originated from the Wuhan province of China and has been exported virtually all over the world. Nigeria as a country is not left out in the spread of the virus; it was however, on the $27^{\text {th }}$ of February 2020 that an Italian citizen was tested and confirmed as Nigeria's first case of Covid-19 infection. Since then, new cases are being reported by the Nigerian Center for Disease Control (NCDC) on a daily. The reason for the rapid spread of the virus in Nigeria and its effects on poor citizens, as Ozili (2020) intimates, is because of weak institutions that are ineffective in responding to the pandemic, and the lack of social welfare programs that would have catered for poor and vulnerable citizens who were affected by the impact of the global health crisis. 
Jurnal Predestination: jurnal of Society and Culture.

Vol .1 No.2, Maret 2021

The above notwithstanding, one of the measures that have been put in place to curb the spread of the virus in the country is the imposition and enforcement of the governmental social distancing policy and movement lockdown (either total or partial) in the country, the effect of which has been felt by most citizens. It must be noted that the provision of social welfare services to vulnerable citizens in the population is the most proven way to protect them from economic hardship in times such as these. In a bid to cushion the effect of the physical/social distancing policy and movement lockdown which has crippled and brought almost all economic activities to a halt, the federal government made pronouncements regarding funds and palliatives, and ordered the Minister of Humanitarian Affairs and Disaster Management to ensure that palliatives in terms of funds and food items are distributed to citizens that are worst off and are affected by the situation. Several individuals, corporate organisations and international donor agencies have contributed to supporting the funds voted for this purpose by the government.

The distribution process, as some analysts have argued, have been marred with inequalities and irregularities that raise the question of who is really vulnerable, and what constitutes the criteria for benefitting from the relief funds? While some still grapple with these questions, the theory of distributive justice seems plausible and workable in answering them. There are, however, varied versions of the theory of distributive justice. These theories, as Allingham (2020) argue, seek to specify what is meant by a just distribution of goods amongst members of the society. These theories are best considered as providing moral guidance for the processes and structures to be used in the distribution of benefits and burdens to citizens in the society. Drawing from the above, the brand of distributive justice that this paper considers plausible and adopts in its assessment of the role of government in the disbursement of the Covid-19 relief funds is the one propounded by John Rawls. Rawls in his Theory of Justice and the Political Liberalism advances a theory of distributive justice which encompasses his notion of justice as fairness and other such schemes as the two principles of justice and difference principle. The high point of his theory in the context of this paper is the difference principle which permits inequalities in the distribution of burdens and benefits to citizens if and only if, the least advantaged are benefitted.

In carrying out the assessment of the distribution of the Covid-19 relief funds from the perspective of Rawls' distributive justice, this paper is divided into three major sections preceding the conclusion. The first section concerns itself with a discourse on what constitutes Rawls' theory of distributive justice, the second section accounts for government and the question of the equitable distribution of the Covid-19 relief funds while the third section accounts for an assessment as well as a prescription of the philosophical orientation that should guide the distribution of the Covid-19 relief funds.

\section{DELINEATING JOHN RAWLS' THEORY OF DISTRIBUTIVE JUSTICE}

The concept of justice has elicited responses from philosophers in history. For Plato, justice entails doing one's job; for Aristotle, it can be said to be treating equals equally and treating unequals unequally; while in the thoughts of Marx, it can be said to be from each according to his ability, to each according to his need. While these conceptualizations hold true and can be said to philosophers philosophizing in their time, it remains to state here that the world, more than ever, stands in dire need of justice. This need permeates all aspects of human life and existence and the continual absence of justice spells doom for humanity. This is because, without justice, peace and development will amount to an illusion. As one will expect, a discourse on distributive justice within the context of the thoughts of John Rawls is what is 
Jurnal Predestination: jurnal of Society and Culture.

Vol .1 No.2, Maret 2021

required in this section. However, it must be noted from the onset that rather than expect a detailed exposition of Rawls understanding of justice, a synopsis of his thoughts on distributive justice will be here presented with the intent of using it as a spring board for anchoring the discourse on the framework for the equitable distribution of the Covid-19 palliatives to the people.

John Rawls (1921-2002) is regarded as one of the greatest of the $20^{\text {th }}$ century and perhaps, its greatest political philosopher. He contributed immensely to discourse on the concept of justice in his book entitled A Theory of Justice (henceforth referred to as TJ) and the Political Liberalism (henceforth referred to as $P L$ ). In the opening pages of $T J$ (1971), Rawls notes the role as well as the importance of justice and argued that it is the first virtue of social institutions. According to Rawls (1971):

Justice is the first virtue of social institutions, as truth is of systems of thought. A theory however elegant and economical must be rejected or revised if it is untrue; likewise, laws and institutions no matter how efficient and well-arranged must be reformed or abolished if they are unjust. Each person possesses an inviolability founded on justice that even the welfare of society as a whole cannot override. For this reason, justice denies that the loss of freedom for some is made right by a greater good shared by others. It does not allow that the sacrifices imposed on a few are outweighed by the larger sum of advantages enjoyed by many. Therefore, in a just society the liberties of equal citizenship are taken as settled; the rights secured by justice are not subject to political bargaining or to the calculus of social interests. The only thing that permits us to acquiesce in an erroneous theory is the lack of a better one; analogously, an injustice is tolerable only when it is necessary to avoid an even greater injustice. Being first virtues of human activities, truth and justice are uncompromising (p. 3).

From the above quotation, it is clear that any theory or guiding principle that is unjust should be either revised or rejected in view of the importance of justice in a society. It is following from this background that Rawls advances his theory of justice with its distributive temper. What should be noted is that distributive justice is primarily concerned with the question of how both benefits and burdens should be allocated in the society. Rawls (1971) expresses his general conception to be a situation where: all social values, liberty and opportunity, income and wealth, and the social bases of self-respect are to be distributed equally unless an unequal distribution of any, or all, of these values is to everyone's advantage. Injustice, then, is simply inequalities that are not to the benefit of all (p. 54). His two principles of justice as he will later argue are a special case of the general conception as stated above. In the TJ, Rawls shows what the principles of justice are, and does so with his analysis of the original position and the veil of ignorance. For him, the appropriate arrangement of the basic structure of the society can best be done by individuals from the hypothetical "original position" from the "veil of ignorance". This is quite plausible for him because such individuals would not be able as it were, to predict how any particular structure or institution (be it social or economic) would affect them. In the original position, to quote Rawls (1971): No one knows his place in society, his class position or social status, nor does anyone know his fortune in the distribution of natural assets and abilities, his intelligence, strength, and the like. I shall even assume that the parties do not know their conceptions of the good or their special psychological propensities. The principles of justice are chosen behind a veil of ignorance. This ensures that no one is advantaged or disadvantaged in the choice of principles by the outcome of natural chance or the contingency of social circumstances. Since all are similarly situated and no one is able to design principles to favor his particular condition, the principles of justice are the 
Jurnal Predestination: jurnal of Society and Culture.

Vol .1 No.2, Maret 2021

result of a fair agreement or bargain. For, given the circumstances of the original position, the symmetry of everyone's relations to each other, this initial situation is fair between individuals as moral persons, that is, as rational beings with their own ends and capable, I shall assume, of a sense of justice (p. 11).

Rawls believes that it is only from this prism that justice can be realized and fairness guaranteed. This is because "behind the veil of ignorance, Rawls claims that risk aversion will overcome all other considerations: one would not risk the little he might have in order to increase what he would receive were he one of the wealthy (Elkins, 2007). The concomitant effect of the above would be the maximization and realization of the welfare of the least welloff and less privileged in society. Regarding the principles of justice, Rawls advances two basic principle of justice in the $T J$ and further expounded them in the $P L$. After proposing various formulations of the principles, the final formulation is that of $P L$. According to him in the $P L$ (2005) while rendering the two principles of justice,

Each person has an equal claim to a fully adequate scheme of equal basic rights and liberties, which scheme is compatible with the same scheme for all; and in this scheme the equal political liberties, and only those liberties, are to be guaranteed their fair value (first principle). Social and economic inequalities are to satisfy two conditions: first, they are to be attached to positions and offices open to all under conditions of fair equality of opportunity; and second, they are to be the greatest benefits to the least advantaged members of the society.

In his analysis of Rawls two principles of justice, Allingham (2020) avers that "these principles are lexically ordered: the first principle has priority over the second; and in the second principle, the first has priority over the second part. For the specific question of distributive justice, as opposed to the wider question of political justice, it is the final stone in the edifice that is crucial: this is the famous difference principle". What should be noted is that Rawls used reflective equilibrium as the method of distribution of a targeted just society, while talking about the allocation of benefits and burdens; Rawls accepts that inequalities exists in the society and hence, he discussed it in his difference principle. The Difference Principle as Rawls argues in the $T J$ is strongly egalitarian in the sense that it ensures that there is a distribution that makes everyone better off. To quote Rawls $T J$, "Assuming the framework of institutions required by equal liberty and fair equality of opportunity, the higher expectations of those better situated are just if and only if they work as part of a scheme which improves the expectations of the least advantaged members of society. The intuitive idea is that the social order is not to establish and secure the more attractive prospects of those better off unless doing so is to the advantage of those less fortunate".

Azam (2007) corroborates the above with specific reference to the second principle when he stresses that there are two elements of the second principle: the first one is called the equality of opportunity and the second element is called the difference principle. It proposes an equal division of the primary goods unless an unequal distribution is to the advantage of the least well-off. To do that, the social contractor will formulate options of distribution and then will accept the one that will maximize the benefit of the worst off. The thinking of Rawls, when properly understood indicates that inequality in the society is like bi-conditionals in logic, they are accepted if and only if it allows the least well-off in the society the latitude to be benefitted. And it is on this note that he argues for the compensation of natural and social inequalities. In $T J$, as quoted in Arneson (2007), Rawls suggests how to draw a line between the misfortune that is society's responsibility and the misfortune that is not by distinguishing between deep 
Jurnal Predestination: jurnal of Society and Culture.

Vol .1 No.2, Maret 2021

and shallow inequalities. The former is associated with inequalities in the "basic structure" of society in this passage:

For us the primary subject of justice is the basic structure of society, or more exactly, the way in which the major social institutions distribute fundamental rights and duties and determine the division of advantages from social cooperation. By major institutions I understand the political constitution and the principal economic and social arrangements... The basic structure is the primary subject of justice because its effects are so profound and present from the start. The intuitive notion here is that this structure contains various social positions and that men born into different positions have different expectations of life determined, in part, by the political system as well as by economic and social circumstances. In this way the institutions of society favor certain starting places over others. These are especially deep inequalities. Not only are they pervasive, but they affect men's initial chances in life; yet they cannot possibly be justified by an appeal to the notions of merit and desert. It is these inequalities, presumably inevitable in the basic structure of any society, to which the principles of social justice apply.

Deducible from the above quotation is the fact that the kind of inequality that the society should be responsible for is that type that is deep and are perhaps, inevitable. Drawing from the above, one can argue that the hardship occasioned by the Coronavirus disease 2019 (Covid-19) fits well into the kind of inequality that Rawls argues is the society's responsibility to try to address. It is also inevitable as the worst-off can do little or nothing to help themselves considering the lock-down of the most part of the State and the effects it has on their subsistent means of livelihood. Furthermore, these principles primarily apply to the basic structure of society and govern the assignment of rights and duties and regulate the distribution of social and economic advantages in perilous times as we have it now (Covid-19 pandemics). This formulation presupposes that, for the purposes of a theory of justice, the social structure may be viewed as having two more or less distinct parts, the first principle applying to the one, the second principle to the other (1971, p. 267).

Distributive justice as theorized by Rawls has come under the sledge hammer of critics. For Allingham (2020), if justice is to be grounded in a choice from behind the veil of ignorance, then it is flawed within the context of its construction. Again, the problem of identifying the least advantaged and defining the primary good is unavoidable. In the same vein, Lamont, J. and Favor, C. (2017) aver that "advocates of strict equality argue that the inequalities permitted by the difference principle are unaccepted even if they benefit the absolute position of the least advantaged". However, what these advocates have not been able to do is to convincingly explain the rationale as well as sustain the argument for preventing the society from materially benefitting the least advantaged when these benefits require a deviation from strict equality. It is on that basis that one can argue that these critiques, their plausibility notwithstanding, do not deride Rawls distributive justice. Hence, Rawls' two principles of justice and the Difference Principle are still potent in showing the path to the equitable distribution of the Coronavirus disease 2019 (Covid-19) relief funds.

\section{Government and the Question of the Distribution of the COVID-19 Relief Funds}

Every responsive government is supposed to make sure that all sectors of society are involved in pandemic preparedness and response. The government is the expected leader and it is in-charge of overall coordination and communication efforts (Onyemachi 2020). In its leadership role, the government through the Ministry of Health or Humanitarian and Disaster 
Jurnal Predestination: jurnal of Society and Culture.

Vol .1 No.2, Maret 2021

Management ought to: appoint and lead the coordinating body for pandemic preparedness and urgent response. The government is supposed to provide and monitor the distribution of the Covid-19 relief materials/funds to the vulnerable in other to ease them from hardship. The paper suggests that, during a pandemic, it is important that the government make sure that households take measures to ensure they have access to accurate information, people should have access to reliable information from sources such as WHO and local and national governments.

The Coronavirus began in Wuhan, Hubei Province, China. Residents who live in Wuhan had some link to large seafood and live animal market, which suggests that the mode of transmission of Coronavirus was from animal to person. The virus has been named SARS CoV-2 and the diseases has been named "Coronavirus disease 2019" abbreviated as "Covid19". The first known patient of Coronavirus started experiencing symptoms in Wuham, China on December 1, 2019 (Ozili, 2020). Since then, there have been millions of recorded cases all over the world with an increasing death toll. It was however on January 30, 2020 that the World Health Organisation (WHO) declared Covid-19 virus as a Public Health Emergency of International Concern (PHEIC) because of its spread to countries of the world and its effect on trades and travels (DAWN 2020). Regarding the spread of Coronavirus to Nigeria, Ebenso and Otu (2020) aver that news broke on the $27^{\text {th }}$ of February that an Italian citizen was Nigeria's first case of Coronavirus disease 2019 (COVID-19). The individual landed at Lagos airport two (2) days earlier on a flight from Northern Italy, and had subsequently travelled from Lagos to Ogun State, western Nigeria where he became ill and was promptly isolated.

While the Federal Ministry of health announced the confirmation of the first case of Covid-19 in Lagos State, Nigeria, in the same communication, the minister of health announced that the multi-sectoral Coronavirus preparedness group led by the Nigerian Center for Disease Control (NCDC) has immediately activated its emergency operation centers (see the Nigerian Education sector Covid-19 response strategy in North East (2020).

Since the first case was recorded in February 2020 in Nigeria, government, at all levels, has set up action committees with the intent of containing the pandemic and cushioning its effect on the masses. To this end, government at all levels has voted monies in billions of naira to these committees. There have also be several donations (in cash and medical equipment) to the government by individuals, international donor agencies, corporate bodies (foreign and local) towards combating the pandemic and ameliorating the sufferings of the people occasioned by the lockdown. In fact, The President of Nigeria said that, the government would put in place measures to "preserve the livelihoods of workers and business owners to ensure their families get through this very difficult time in dignity." He said that "the most vulnerable in our society" would receive Conditional Cash transfers (CCT) register, an ongoing government initiative to cater for the less privileged and the poor in the society be increased from 2.5 million to 3.5million people.

These donations and contributions were meant to be converted into some form of palliatives and relief funds for the people. The crux of this paper, resulting from the lockdown is the effect of the Coronavirus pandemic on the average Nigerian, the most part of whose survival depends largely on daily earnings. This constitutes about $65 \%$ of Nigerians who work in the informal sector - the street hawkers, barbers, mechanics, hairdressers, bricklayers, farmers amongst others who already live below the poverty line and are considered as the poorest of the poor (see Page 6 of the joint memo by the Civil Society Organisations in Nigeria). While these efforts are somewhat commendable, the question of justice and equity in the distribution of the contributions that have been made as well as the monies voted for the same have been raised. In fact, a consortium of anti-corruption organisations, under the 
Jurnal Predestination: jurnal of Society and Culture.

Vol .1 No.2, Maret 2021

umbrella of the Upright for Nigeria, stand against corruption campaign called on the Federal and state governments to immediately publish the names of all the beneficiaries of the government palliatives to ensure transparency and accountability in the distribution of the Covid-19 palliatives.

Another question that has been raised is that how many people have really been able to access these relief funds either in terms of cash transfers or palliative? It must be noted that very many of those who need these palliatives do not have access to them and hence, the imperativeness of advancing a philosophical operation that will help attain a fair and just distribution of these palliatives. To this end, this paper finds John Rawls distributive justice as germane to this task.

\section{Assessing the Role of the Government in the Distribution of Relief Funds from the Prism of John Rawls}

It must be stated from the beginning of this section that the task of comprehensively assessing and evaluating the distribution of the Covid-19 relief funds and palliatives within the context of a kind of evaluation that is summative may not be very much exhaustive. This is because the Covid-19 pandemic has not been conquered completely (at the time of writing this paper) neither has the lockdown been fully relaxed for the people to live their normal lives. It is only when the virus ceases to hold sway and to be a public health emergency of international concern (PHEIC), that the success or failure of the attempts of government at all levels at assuaging the effect of the pandemic on the people through the relief funds and other palliatives can be successfully and sufficiently assessed. However, the evaluation that is intended in this paper is what is called the initial/on the spot evaluation. This evaluation is intended to appraise the success and the gains so far recorded as well as to show the areas that leave much to be desired.

This paper argues that it is the responsibility of government to make adequate provisions for the economic and healthcare needs of its citizens to the best of its ability and within the confines of its resources. It is to this effect that the government usually calls on the corporate world and individuals to support its efforts when it is constrained or faced with an apparent lack of resources. Again, government is supposed to be concerned and driven by the resolve to deliver the goods of human flourishing to the people especially at a time when its citizens are grappling with a global pandemic such as the Coronavirus 2019. Rawls seems to hold the above view when he argues in the $T J(1971: 250)$ that "government is assumed to aim at the common good, that is, at maintaining conditions and achieving objectives that are similarly to everyone's advantage".

A critical look at the Covid-19 relief funds in Nigerian and other palliatives reveals that government at all levels have voted monies in billions into this fund. Corporate organizations, foreign and local have also contributed billions of dollars to this fund. This is not forgetting the millions of naira that have been donated by individual, celebrities and businessmen to this fund. Besides, other non-monetary interventions in terms of medical equipment, isolation centres, ambulances, amongst others have also been donated to the Federal and State governments. However, when one takes a look at the distribution of these funds and palliatives with an unjaundiced eye and from the screen of objectivity, one finds out that the funds and the palliatives have not been evenly and justifiably distributed. Aside the question of who is to be considered vulnerable? What is the total number of the vulnerable in Nigeria? Is there any statistical tool for determining the numbers of the vulnerable? How do we know if all the vulnerable really benefitted from this relief fund? One finds a disparity in the distribution with some States in some regions of the country giving out as much as a full 
Jurnal Predestination: jurnal of Society and Culture.

Vol .1 No.2, Maret 2021

bag of either $10 \mathrm{~kg}, 25 \mathrm{~kg}$ or $50 \mathrm{~kg}$ of rice and while in other States, one finds people leaving the distribution centres with cups of rice and a few cubes of Maggi or loaves of bread.

Again, the above situation leaves us with the questions of who is vulnerable and what is the criterion for determining the people who benefit from the Covid-19 relief funds? As dicey as these questions may be, I will attempt to answer them in conjunction with Rawls' principle of distributive justice. As stated earlier, Rawls sanctions inequalities, in so far as it is geared towards benefitting the least favoured, that is, the vulnerable in the society. While Rawls does not answer the question of how the society can identify the least advantaged people, he rather gives a lead on how to identify the representatives of the least advantaged people in the society. For Rawls, the well-being of the representatives of the least advantaged in the society is assessed by their allocation of what he calls the primary goods. In his division of the primary goods, Rawls classifies two broad groups of primary goods: the first is the social primary goods which include liberty, income, opportunities and wealth (the subject matter of the first and second parts of the second principle of justice) and the second group is the natural primary goods (which for the most part have personal characteristic). It must however be noted that Rawls' justice as fairness is concerned with the distribution of social primary goods.

For Rawls, a just system is such that is being situated behind a veil of ignorance where the representatives of government do not know anything about themselves or their situations, and accordingly seek equality. This veil is one that essentially blinds them to all facts about themselves so they cannot tailor their own advantages. The intention is that as the parties to the contract have no information about themselves they necessarily act impartially, and thus as justice as fairness requires. As no one knows his circumstances, no one can try to impose principles of justice that favor his particular condition. But this is completely the opposite for the Nigerian system; this is because the representatives consider their own interest first, before others. They tailor the criteria for the distribution of palliatives to their own advantage and that of their ally.

Hermeneutically, one can argue that the government can identify the economically least advantaged in the society just like Rawls advances, by assessing the allocation of wealth, opportunities, income and the nature of the people's means of livelihood. In this manner, the government can reach them through their various trade associations, local community development associations and by dealing directly with the people in the countryside and the urban centres. While one can also argue that the most part of citizens are living below the poverty level and hence, are vulnerable, it is doubtful how far one can sustain the argument for the fact that the level of vulnerability is the same across board. To this end, the prescription of this paper, following from Rawls difference principles is that, the very least disadvantaged, the artisans who usually need to work on a daily basis to be able to sustain themselves and their families; the unemployed, the petty traders who needs to buy goods, retail same and survive from the proceeds (gains) of their sales; the private school teachers whose employment are temporarily put on hold and hence, cannot earn salaries to survive and other groups whose earnings and means of livelihood are basically dependent on what energy they are able to exert daily constitutes the vulnerable and the least advantaged. Consequently, the Covid-19 relief funds should be made available to them as a matter of necessity to cushion the effects of the Coronavirus pandemic.

Following the above very closely is the question of equality of opportunity. While it has been agreed that the only form of inequality that is accepted in Rawls scheme is that which benefits the least advantaged, the paper argues that the distribution of food items is not the economic distribution that is important to the people on the one hand. It also argues on the 
Jurnal Predestination: jurnal of Society and Culture.

Vol .1 No.2, Maret 2021

other hand that even within the context of the distribution of food items, conditional cash transfer (CCT), Trader money, market money and other social welfare schemes, the principle of equality of opportunity which Rawls argues for in his distributive justice should be allowed to play out. In this context, the proclivity and inclination to think that one ethnic or religious group is more human than the others and hence, ensuring that the said group benefits from this relief funds to the detriment of the other will be taken care of. When this is done, such discriminatory index and primordial sentiments as ethnicity, religion and gender will be ruled out.

The above argument is based on the fact that the Coronavirus disease (Covid-19) is a global pandemic that threatens our collective existence. It is also based on the fact that ethnicity, religion etc. are not the substance of our existence; they are rather, accidents within the context of the Aristotelian understanding of substance and accident. Again, the lockdown and stay at home order of the government is given to all citizens, regardless of the ethnic and religious affiliation so, these twin factors should not be used to determine who get what, how and when within the context of the distribution of the Covid-19 relief funds and the question of equality of opportunity.

\section{CONCLUSION}

In the foregoing, attempt has been made to undertake on the spot assessment of the distribution of the Coronavirus 2019 (Covid-19) relief fund in Nigeria. This attempt was guided by the question of vulnerability as well as that of what are the criteria for benefitting from the relief fund? As have been argued earlier, the distribution process, when viewed with an unjaundiced eye, has not been equitable and leaves much to be desired. That notwithstanding, the philosophical dimension that this paper brings to the discourse with the intent of guiding the distribution process is Rawls' distributive justice that is hinged on the two principles of justice and the difference principle. The high point of this orientation spells out the fact that in the distribution of the burdens and benefits to citizens in the society, equality should be the watchword and inequalities are accepted in so far as they benefit the least advantaged and vulnerable in the society. Drawing from the above, this paper has argued that considering the effects of the Coronavirus pandemic occasioned by the total or partial lockdown in most States of the Federation, the least well-off or the least advantaged in the society (the artisans, the petty traders, the pensioner and senior citizens, people that live below the poverty threshold, those who have to work daily to earn wages for survival amongst others) should benefit as a matter of necessity from the relief fund. The paper also argued for equality of opportunity in the distribution process devoid of such discriminatory factors as ethnicity and religion. The conclusion that is reached in this paper is that, the flaws of Rawls' distributive justice notwithstanding, it is yet potent and finds relevance in the search for a philosophical orientation that should guide the government in her task of equitably distributing the Covid-19 relief funds in Nigeria.

\section{REFERENCES}

Allingham, M (2020) "Distributive Justice" in Fieser, J and Dowden, B (Edited) Internet Encyclopedia of Philosophy online http://www.iep.utm.edu/distributive/ Retrieved on the $19 / 05 / 2020$.

Arneson, R (2017) "Rawls, Responsibility and Distributive Justice” CUEX199-03 Vol. 2. 
Jurnal Predestination: jurnal of Society and Culture.

Vol .1 No.2, Maret 2021

Azam, G. (2007) 'Rawls' Theory of Distributive Justice and the Role of Informal Institutions to get People Access to Healthcare in Bangladesh" Philosophy and Progress. JuneDecember 2007.

Ebenso, B and Otu, A. (2020) "Can Nigeria Contain the COVID-19 outbreak Using Lessons From Recent Epidemics?" The Lancet Global Health.

Elkins, D (2012) Responding to Rawls: Towards a Consistent and Supportable Theory of Distributive Justice. N. P.

Lamont, J and Favor, C (2017) "Distributive Justice" in Edward N. Zalta (ed.) The Stanford Encyclopedia of Philosophy online, http://plato.stanford.edu/archives/spr2017 /entries/distributive. Retrieved on 20/05/2020.

Onyemachi, F. C. (2020). Complementary Leadership: A Neglected Key to National Security Issues in Nigeria. GNOSI: An Interdisciplinary Journal of Human Theory and Praxis, 3(1), 76-84.

Ozili, P (2020) "COVID-19 Pandemic and Economic Crisis: The Nigerian Experience and Structural Causes" Retrieved from Https://www.researchgate.net/publication/340439471. 23/05/2020.

Rawls, J. (2005) Political Liberalism (Expanded version). New York: Columbia University Press.

Rawls, J. (1971) A Theory of Justice. Cambridge, Massachusetts: The Belknap Press of Harvard University. 